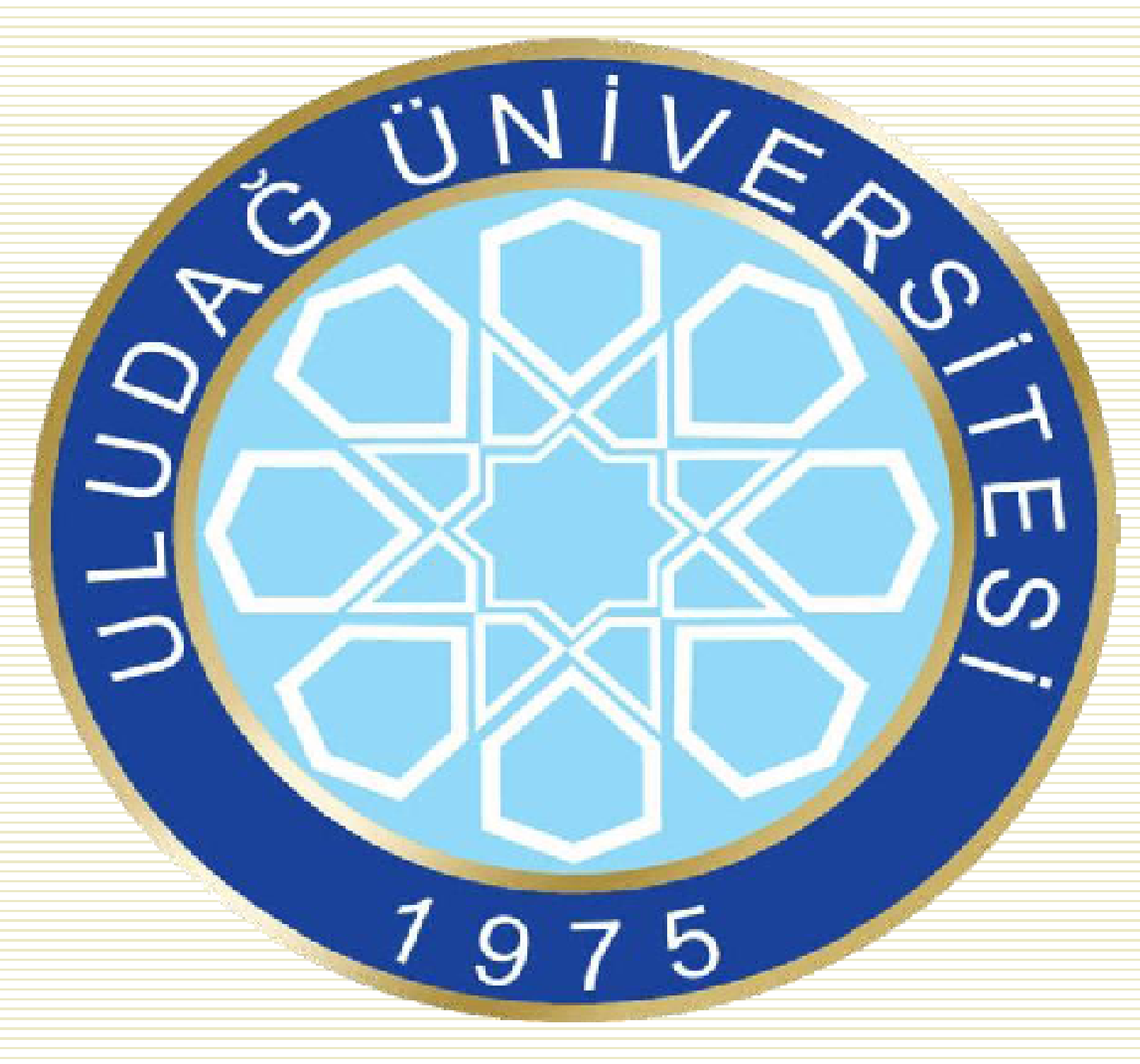

\title{
Thyroid Hormone Resistance: A Case Report
} SONER CANDER ${ }^{2}$, ESRANUR BULBUL ${ }^{3}$ ERDINC ERTURK ${ }^{1}$, CANAN ERSOY $^{1}$

1ULUDAG UNIVERSITY MEDICAL SCHOOL ENDOCRINOLOGY AND METABOLISM DEPARTMENT ${ }^{2}$ SEVKET YILMAZ TRAINING AND RESEARCH HOSPITAL ENDOCRINOLOGY AND METABOLISM DEPARTMENT ${ }^{3}$ ULUDAG UNIVERSITY MEDICAL SCHOOL INTERNAL MEDICINE DEPARTMENT

\section{INTRODUCTION:}

Classic thyroid hormone resistance (THR) occurs per every 400000 live birth. TRH should be considered along with thyroidstimulating hormone (TSH)-producing adenomas when normal or high levels of TSH not consistent with hyperthyroidism is present.

\section{CASE REPORT:}

A 45-year old woman admitted to our institution with multiple solitary thyroid nodules. Her serum free thyroxine(fT4), free triiodothyronine(fT3) and TSH levels were high. In thyroid USG examination, it was found that there were 3-4 nodules in the right thyroid lobe sized $9 * 6.5 \mathrm{~mm}$ and nodules with hypoechoic solid nature which largest of them was $16 * 11 \mathrm{~mm}$ in the left thyroid lobe. Fine needle aspiration biopsy(FNAB) was performed on thyroid nodules and results were benign. Sella magnetic resonance imaging(MRI) was performed with diagnosis of secondary hyperthyroidism. In sella MRI, it was found that there was an adenoma sized $11 * 9 * 10 \mathrm{~mm}$ in pituitary gland. Other anterior pituitary hormone levels were normal. There were no eyesight pathology. L-thyroxin treatment was ceased due to the euthyroid status of the patient. During tests performed for excluding THR, it was found that alpha subunit(ASU) level was in normal range and molar ASU/TSH ratio was below 1 . Then, TRH stimulation test was planned. TSH levels at $0,15,30,45$ and $60 \mathrm{~min}$ after TRH administration were obtained. It was observed that there was an extensive response consistent with THR in TSH levels with TRH test.
Patient was enrolled in follow-ups with the diagnosis of THR and non-functional hypophysis adenoma.

\begin{tabular}{ll}
\hline TRH stimulation test & \\
\hline TSH $0 \mathrm{~min}$ & $8 \mu \mathrm{lU} / \mathrm{mL}$ \\
TSH $15 \mathrm{~min}$ & $57 \mu \mathrm{lU} / \mathrm{mL}$ \\
TSH $30 \mathrm{~min}$ & $76 \mu \mathrm{lU} / \mathrm{mL}$ \\
TSH $45 \mathrm{~min}$ & $75 \mu \mathrm{lU} / \mathrm{mL}$ \\
TSH $60 \mathrm{~min}$ & $67 \mu \mathrm{lU} / \mathrm{mL}$
\end{tabular}

Thyroid Function test
$\begin{array}{ll}\text { TSH } & 15.40 \mu \mathrm{lU} / \mathrm{mL} \\ \text { fT3 } & 4.78 \mathrm{pg} / \mathrm{mL} \\ \text { fT4 } & 1.49 \mathrm{ng} / \mathrm{dL}\end{array}$

\section{CONCLUSION:}

In clinical practice, differentiation between TSH-secreting adenomas and THR is quite difficult. Predominence of hyperthyroidism symptoms and presence of macroadenoma in hypophysis make the possibility of TSHsecreting adenoma more convincing. However, most of the patients are asymptomatic. TRH stimulation test is the most valuable test for diagnosing. Its sensitivity and specifity were reported as $90 \%$ and $80-90 \%$, respectively. In conclusion, THR should be considered before diagnosing as TSH-secreting adenoma in patients evaluated for secondary hyperthyroidism and identified with pituitary adenoma. 